\title{
Turquality: an innovative unique model for making global brands out of Turkish products
}

\section{Introduction}

Turkey is a European-Middle Eastern-Asian country which has almost doubled its foreign trade in three years and which is seeking to continue its economic expansion by trying to implement new ways of export promotion and fresh incentives for global brand-building.

The elimination - at the end of 2004 - of quantitative import restrictions under the World Trade Organisation (WTO) Agreement on Textiles and Clothing put an end to a complex trade regime built up over decades (OECD Policy Brief, 2004) and had huge implications for Turkey, which had been one of the main players involved in the supply chain.

Turkey put in place a tentative restriction for a period of three years beginning 1 January 2005 on products of Chinese origin, but the Turkish government still had to consider and address the critical issues such as 'Who stands to lose and to gain?', 'Where will jobs be lost and new markets found?' and 'How can the government help the textile and clothing industries (and, further on, other industries) adjust to this new trade regime?'. Searching for helpful answers to the above questions years previously, then Foreign Trade Under-Secretary Kursad Tuzmen, now State Minister for Foreign Trade, devised a project called Turquality to ensure that Turkish industries primarily textiles and clothing which were more exposed to risk - were ready to compete in a new and less distorted trading arena; and, at the same time, to create a WTOcompliant incentive policy that would assist Turkish products become worldwideknown brands.

In today's highly competitive business world, not only the image of the brand itself but also the image of the country where it was produced is valuable; and marketers are cognisant that country of origin affects consumers' product evaluations (Bilkey and Nes, 1982; Erickson et al, 1984; Han, 1989; Han and Terpstra, 1988; Johansson et al. 1985; Al-Sulaiti and Baker, 1998). Research has shown that country of origin not only affects consumers' perceptions of product quality (Hong and Wyer, 1989, 1990; Johansson et al, Johansson and Thorelli, 1985; Papadopoulos and Heslop, 1993) but also of brand image (Han and Terpstra, 1988), purchasing decisions (Heslop and Papadopoulos, 1993) and the propensity to use a product's 'Made In' label (Han and Terpstra, 1988; Johansson et al, 1985; Tse and Gorn, 1993). When people consider buying a Mercedes-Benz car, they take the German talent for engineering into account and when someone talks about Germany, especially about cars, they most probably directly imagine Mercedes-Benz. This mutual effect has led the business world to treat nations as global brands. Country-of-origin markings as they apply to products or even components can be an effective strategic tool for global markets (Clarke et al, 2000). From this perspective, it is particularly crucial that Turkey, which strongly aspires to the maintenance of an export-led strategy, finds a better and more innovative way of enhancing competitive edge and improving its image and of its products, so as to have greater profit margins on exports. This can be achieved by 
supporting the development of company-level expertise in higher value-added service segments in the supply chain such as design, sourcing, retail distribution, PR, aftersales service and marketing.

Turquality takes its roots in the effects of the concept of country of origin. Country of origin may be identified in many ways. According to some authors (Wang and Lamb, 1983), country of origin effects provide intangible barriers to entry into new markets in the form of a negative bias towards imported products. Some researchers define country of origin as the country where the corporate headquarters of the company marketing the product is located (Johanson et al, 1985; Ozsomer and Cavsugil, 1991). In most studies, however (Samiee, 1994; Bilkey and Nes, 1982; Cattin et al, 1982; Han and Terpstra, 1988; Lee and Schaninger, 1996; Papadopoulos, 1993; White, 1979), the country of origin effect was defined in terms of the country of manufacture or assembly. Some scholars (Bannister and Sounders, 1978; Chasin and Jaffe, 1979; Nagashima, 1970) use the term 'Made In....' to define a product's country of origin.

When we look more closely at studies on the country of origin effect, it is easier and more meaningful to describe why the concept of Turquality emerged. One study (Schooler, 1965) showed that products made in less developed countries were not evaluated as quality products. Consumers were biased for or against products from a less developed country when they were evaluating products made in different or even less developed countries. According to another study (Papadopoulos et al, 1987), both consumers and industrial buyers are affected by 'Made In...' images. According to the findings of one other important study (Han, 1989), country image can be used in either of two directions. It is used as a 'halo' construct where the image of the country is used to consider products that consumers know little about and, alternatively, it is used as a summary construct: where consumers become familiar with a country's products, the image of the country may become a construct that summarises their beliefs about product attributes and which directly affects their attitudes towards the brand. Some researchers (Khachaturian and Morganosky, 1990) concluded that associating a brand with less industrialised countries could potentially lower the quality image of that brand type; moreover, the less industrialised the country of origin, the greater the potential decline in the quality image. Some researchers (Baker and Currie, 1993) have gone further and suggested that the concept of country of origin should be considered as the fifth element in the marketing mix.

It can easily be seen that the country of origin effect is extremely important when exporting products. Consequently, the Turquality concept may serve as an umbrella or supra-structure not only for enhancing the quality but also increasing the reputation of products originating from Turkey.

This article studies the general regulatory layout of the Turquality project, drawing comparisons with analogous projects implemented in other countries. It also compiles necessary data on the companies which have been certified and highlights the incentive regime of Turkey, while discussing the challenges involved. 


\section{Turquality: definition and scope}

\section{Definition}

Turquality is a concept made up of 'Turk' and 'quality' and is defined as an accreditation system encompassing all processes from production to marketing, and from sales to after-sales services, of products having a competitive advantage and branding potential.

\section{Scope}

This project/system primarily aims to establish standards for quality and reliability, image, after-sales service and logistics and, subsequently, to promote the companies possessing these standards under this quality stamp, thus strengthening the international image of Turkish products (Turkish Daily News 12 October 2006). Support began in the first place in the textile industry and then moved on to other industries in 2006. Currently, 33 companies are supported (Milliyet 14 December 2006) and the primary target markets have been determined as Russia, France, Britain and Spain.

Within the above-mentioned aim of accelerating branding processes in the companies supported, the Foreign Trade Under-Secretariat released a communiqué in 2003 (Official Gazette 25213, 28 August 2003) and, within this framework (Communiqué 2003/3), branding incentives have been further developed while long-term, high value supports have been launched for branding activities.

The framework will provide support for companies and Turkish fashion designers under a wide range of incentives: from the cost of brand registrations to marketing and PR activities; from opening stores, warehouses, branches, offices and showrooms to the payment of rental expenses and commissions for stands at fairs; from the decoration costs of franchise stores and the cost of quality certificates to all expenditures pertinent to branding activities.

Apart from the supports mentioned above, the Export Union and producer foundations are supported for all PR, advertising and marketing expenditures which are relevant to their industries within the framework of this communiqué, later updated as Communiqué 2006/4 (Official Gazette 26177, 24 May 2006).

Services provided within this system - which has been devised on the assumption that the individual efforts of Turkish companies to create a positive 'Turkey' and 'Made In Turkey' image would not be enough - will be realised on two levels. On the first, basic support services such as training, short-term consulting modules and international support will be provided to companies to render them excellent in terms of their management. On the second, 'potential champions' will be chosen from among the companies which have passed the first level; these will be eligible for further support services such as tailored strategic consulting, coaching and hands-on consultancy.

\section{Turquality vision}

The Turquality vision is outlined within three areas ${ }^{1}$ :

- to help Turkish industry re-position itself strategically

- to locate brand image within world standards

1 Presentation/conference notes made at ITKIB, 06 January 2004. 
- to be the catalyst for change to underpin the success of Turkish products and firms around the world.

\section{Turquality mission}

Turquality has four principal mission statements given the complex and tough structure of the hyper-competition which today reigns in international markets:

- to support the branding expenditures of the selected Turkish brands

- to provide coaching and consulting services to Turkey's best companies in order to allow them to compete globally

- to act as a catalyst and incubator for the selected Turkish brands

- to provide PR and communications activities in order to create and promote a positive Turkish image.

The Turquality concept is to construct a platform that selects the companies and provides support for the enhancement of the production skills, infrastructure and strategic capability of, in the first place, Turkish ready-to-wear textile companies. In other words, the concept is shaped so as to enable companies to compete successfully in today's highly globalised world at the local level with new and high quality products, concepts and brands.

With the Turquality concept, the image of Turkish products on the market will relate directly to quality. The primary criteria for being a global brand is to adopt global quality standards.

To conduct global PR activity, the first introductions took place in Moscow on 16 December 2004 (Turkish Daily News 17 January 2007). The participation of Russian TV channels such as NTV, TNT, DTV, TV3 and REN TV, and Sertab Erener's performance, with other attractions, were very promising for the future. An outlet for Turkish brands was also opened in one of the largest Japanese malls, called Takashimaya. In addition, a brand-positioning seminar was held by brand guru Jack Trout in Istanbul on 30 May 2006, while joint management development programme training courses were held by Koç and Sabanci Universities. A sum of $\$ 9.5 \mathrm{~m}$ has been spent on TURQUALITY® inspection and communication activities (Turkish Daily News 17 January 2007); when this figure is added to the $\$ 18 \mathrm{~m}$ spent on the restructuring of firms (Turkish Daily News 13 October 2006), total expenditure stands at $\$ 27.5 \mathrm{~m}$.

Being a global brand is a very difficult process. A still-developing country, Turkey has to strive much harder and to make more investment relative to its western counterparts. However, Turkey has some important advantages: reaching high standards in the textile industry, and in particular the perfect quality and marketability of those products supported under the Turquality concept, and assuring that this quality meets consumers' expectations, are realities that need to be mentioned. At the same time, having foreign trade with EU countries provides a competitive advantage in terms of logistics: around 52.8\% of foreign trade is conducted with EU countries (TUIK, 2006). Other things that should be taken into account are marketing, PR and providing continuous improvement and creative thinking activities.

\section{Regulatory framework}

Funding for the initiative has its legal basis in Communiqué 2006/4 - initially Communiqué 2003/3 - the conditions for which are set out on a comparative basis in Table 1: 
Table 1 - Regulatory conditions for financial support

\begin{tabular}{|l|c|c|}
\hline Criteria & $\begin{array}{c}\text { 2003/3 } \\
\text { (Brand Support) }\end{array}$ & $\begin{array}{c}\text { 2006/4 (Turquality \& Brand } \\
\text { Support) }\end{array}$ \\
\hline Maximum limit & $\$ 1450000$ per annum & $\begin{array}{c}\text { No upper limit for } \\
\text { Turquality }\end{array}$ \\
\hline Funding period & Four years & Five years \\
\hline Number of brands supported & One & Two (three for holdings) \\
\hline Designer support & No & Yes (maximum three) \\
\hline
\end{tabular}

1 Communiqué 2006/4, Art. 20 §a.

2 Communiqué 2006/4, Art. 20 §b.

These communiqués are regulated based on the Decision on Government Support For Exports (Council of Ministers Decision 94/6401 dated 27 December 1994).

The process of enlistment

A company needs to apply directly to the Foreign Trade Under-Secretariat with a project report (Project Suggestion Form), including its branding activities and budget. The company will subsequently be listed if it falls within the scope for support (or else rejected) by the Turquality Committee.

- only two selected brands (three for holding companies) will be adopted within the scope for support

- these brands must have been registered with the Turkish Institute of Patents, or the registration application should have been made and publicised in at least half the target markets specified on the Project Suggestion Form

- the project application form has to be filled in correctly and completely.

After an assessment of the application has been completed by the Foreign Trade Under-Secretariat, the company is notified whether or not it is to be enlisted as falling within the scope for support. The initial assessments are made by Deloitte - a company appointed to handle the consultancy part - and are made under these performance criteria:

- strategic planning and organisational performance management

- financial performance

- supply chain management

- brand management

- brand strength

- product design and research \& development

- marketing, customer and commerce management

- corporate governance

- human resources management

- information technologies management 


\section{The mechanism of support}

Listed companies are supported in terms of training (Koç and Sabanc1 Universities), product quality improvement (Werner International), strategic marketing and brand building (Trout \& Partners), management consultancy (Deloitte) and communications strategy (DDF Advertisement Agency).

After being listed for support, companies do have to fulfil several obligations:

- company expenditures subsequent to enlistment may be supported but no expenditures incurred before that date are supportable

- all official documents have to be issued under the full title of the company and all expenditures should have been paid by the supported company with the aid of the legal banking system

- after being listed for support, a company can benefit from payment for up to consecutive five years

- at least $50 \%$ of the activities mentioned on the project has to be carried out; otherwise, there may be decrease in the amount of support or else the company may be totally eliminated from the project

- official documents concerning supported expenditures have to be stamped by the Trade Counsellor of the Turkish Embassy in the country where the expense has been made and should be presented to the General Secretariat of the Export Union within six months

- in spite of the six-month period within which all other official documents must be presented, brand registration expenditures have the longer period of eighteen months.

\section{Certification criteria and the certified companies}

Certificates were first given to fifteen entitled companies and three fashion designers on 25 November 2004. After an audit process (second selection), completed between April and September 2006, 33 companies in total received their certificates on 13 December 2006. In the first leg of this new selection, the 15 brands and three fashion designers originally selected were placed in a Champions Pool along with brands that were the existing beneficiaries of the government's continuing Brand Incentive scheme (Communiqué 2003/3). This group was then inspected by Deloitte. In the light of the Deloitte reports, the TURQUALITY® committee selected 33 out of the 64 brands in the pool (Turkish Daily News 17 January 2007).

Table 2 - Companies falling within the scope of support

\begin{tabular}{|l|c|c|c|c|}
\hline Company & Sector & $\begin{array}{c}\text { Brand(s) sup- } \\
\text { ported }\end{array}$ & $\begin{array}{c}\text { Annual } \\
\text { turnover (\$) }\end{array}$ & Website \\
\hline $\begin{array}{l}\text { Mercek } \\
\text { Holding A.S. }\end{array}$ & $\begin{array}{c}\text { Textile \& } \\
\text { garment }\end{array}$ & Abbate & 51145625 & $\begin{array}{c}\text { Www.ab- } \\
\text { bate.com.tr }\end{array}$ \\
\hline Bilsar Tekstil & $\begin{array}{c}\text { Textile \& } \\
\text { garment }\end{array}$ & Bil's White & & www.bilsar.com \\
\hline Eroǧlu Tekstil & $\begin{array}{c}\text { Textile \& } \\
\text { garment }\end{array}$ & Collin's & 85728155 & $\begin{array}{c}\text { www.eroglu- } \\
\text { group.com.tr }\end{array}$ \\
\hline
\end{tabular}


Turquality: an innovative unique model for making global brands out of Turkish products

\begin{tabular}{|c|c|c|c|c|}
\hline Company & Sector & $\begin{array}{l}\text { Brand(s) sup- } \\
\text { ported }\end{array}$ & $\begin{array}{c}\text { Annual } \\
\text { turnover (\$) }\end{array}$ & Website \\
\hline Orka Tekstil & $\begin{array}{l}\text { Textile \& } \\
\text { garment }\end{array}$ & Damat Tween & & $\begin{array}{l}\text { www.da- } \\
\text { mat.com.tr }\end{array}$ \\
\hline $\begin{array}{l}\text { DSD Deri San. } \\
\text { Dis Ticaret }\end{array}$ & $\begin{array}{l}\text { Textile \& } \\
\text { garment }\end{array}$ & Derri & 200000000 & www.derri.net \\
\hline Esas Tekstil & $\begin{array}{l}\text { Textile \& } \\
\text { garment }\end{array}$ & Esas & $\mathrm{n} / \mathrm{a}$ & $\mathrm{n} / \mathrm{a}$ \\
\hline Harmanli Deri & $\begin{array}{l}\text { Textile \& } \\
\text { garment }\end{array}$ & Harmanli & $\mathrm{n} / \mathrm{a}$ & $\begin{array}{l}\text { www.harman- } \\
\text { li.com }\end{array}$ \\
\hline İpekyol Giyim & $\begin{array}{l}\text { Textile \& } \\
\text { garment }\end{array}$ & İpekyol & $\mathrm{n} / \mathrm{a}$ & $\begin{array}{l}\text { www.ipeky- } \\
\text { ol.com.tr }\end{array}$ \\
\hline Çak Tekstil & $\begin{array}{c}\text { Textile \& } \\
\text { garment }\end{array}$ & Little Big & 103969296 & $\begin{array}{l}\text { www.lit- } \\
\text { tlebig.com.tr }\end{array}$ \\
\hline Mithat Giyim & $\begin{array}{l}\text { Textile \& } \\
\text { garment }\end{array}$ & Mithat & 62761295 & $\begin{array}{l}\text { www.mithatgiy- } \\
\text { im.com.tr }\end{array}$ \\
\hline $\begin{array}{l}\text { Altinyildiz } \\
\text { Mensucat }\end{array}$ & $\begin{array}{c}\text { Textile \& } \\
\text { garment }\end{array}$ & Network & 120868946 & $\begin{array}{l}\text { www.altinyild- } \\
\text { iz.com.tr }\end{array}$ \\
\hline Polo Giyim & $\begin{array}{l}\text { Textile \& } \\
\text { garment }\end{array}$ & Polo Garage & 47794117 & $\begin{array}{l}\text { www.pologa- } \\
\text { rage.com.tr }\end{array}$ \\
\hline Gürmen & $\begin{array}{c}\text { Textile \& } \\
\text { garment }\end{array}$ & Ramsey & $\mathrm{n} / \mathrm{a}$ & $\begin{array}{l}\text { www.gurmen- } \\
\text { group.com }\end{array}$ \\
\hline Ipas Iplik & $\begin{array}{c}\text { Textile \& } \\
\text { garment }\end{array}$ & Foreigner & $\mathrm{n} / \mathrm{a}$ & $\begin{array}{l}\text { www.ipastex- } \\
\text { tile.com }\end{array}$ \\
\hline Desa & $\begin{array}{c}\text { Textile \& } \\
\text { garment }\end{array}$ & Desa & $\mathrm{n} / \mathrm{a}$ & www.desa.com.tr \\
\hline $\begin{array}{l}\text { Gilan } \\
\text { Kuyumculuk }\end{array}$ & Jewellery & Gilan & $\mathrm{n} / \mathrm{a}$ & $\begin{array}{l}\text { www.gi- } \\
\text { lan.com.tr }\end{array}$ \\
\hline Gulom Tekstil & $\begin{array}{c}\text { Textile \& } \\
\text { garment }\end{array}$ & Redstar & $\mathrm{n} / \mathrm{a}$ & $\begin{array}{l}\text { www.redstar- } \\
\text { jeans.com }\end{array}$ \\
\hline $\begin{array}{l}\text { Goldas } \\
\text { Kuyumculuk }\end{array}$ & $\begin{array}{c}\text { Textile \& } \\
\text { garment }\end{array}$ & Goldas & $\mathrm{n} / \mathrm{a}$ & www.goldas.com \\
\hline Vivid Giyim & $\begin{array}{c}\text { Textile \& } \\
\text { garment }\end{array}$ & Vivid & $\mathrm{n} / \mathrm{a}$ & $\begin{array}{l}\text { www.viv- } \\
\text { id.com.tr }\end{array}$ \\
\hline Saray Holding & $\begin{array}{l}\text { Textile \& } \\
\text { garment }\end{array}$ & Saray & $\mathrm{n} / \mathrm{a}$ & $\begin{array}{l}\text { www.sarayhold- } \\
\text { ing.com.tr }\end{array}$ \\
\hline Şölen Çikolata & $\begin{array}{l}\text { Non-durable } \\
\text { goods }\end{array}$ & Șölen & 95707331 & $\begin{array}{l}\text { www.so- } \\
\text { len.com.tr }\end{array}$ \\
\hline Hidromek & Durable goods & Hidromek & $\mathrm{n} / \mathrm{a}$ & $\begin{array}{l}\text { www.hid- } \\
\text { romek.com.tr }\end{array}$ \\
\hline
\end{tabular}




\begin{tabular}{|c|c|c|c|c|}
\hline Company & Sector & $\begin{array}{l}\text { Brand(s) sup- } \\
\text { ported }\end{array}$ & $\begin{array}{c}\text { Annual } \\
\text { turnover (\$) }\end{array}$ & Website \\
\hline $\begin{array}{l}\text { Atasay } \\
\text { Kuyumculuk }\end{array}$ & Jewellery & Atasay & 90748964 & www.atasay.com \\
\hline Anadolu Group & $\begin{array}{l}\text { Non-durable } \\
\text { goods }\end{array}$ & Efes Pilsen & 391941851 & $\begin{array}{l}\text { www.efespilsen.c } \\
\text { om.tr }\end{array}$ \\
\hline Eti & $\begin{array}{l}\text { Non-durable } \\
\text { goods }\end{array}$ & Eti & 193954708 & \\
\hline Sarar Giyim & $\begin{array}{c}\text { Textile \& } \\
\text { garment }\end{array}$ & Sarar & 106437587 & www.sarar.com \\
\hline Pasha Deri & $\begin{array}{l}\text { Textile \& } \\
\text { garment }\end{array}$ & Viaveneto & $\mathrm{n} / \mathrm{a}$ & $\begin{array}{l}\text { www.pashade- } \\
\text { ri.com }\end{array}$ \\
\hline Eke Tekstil & $\begin{array}{c}\text { Textile \& } \\
\text { garment }\end{array}$ & Hamam & $\mathrm{n} / \mathrm{a}$ & $\begin{array}{l}\text { www.hamam.co } \\
\text { m.tr }\end{array}$ \\
\hline Zorlu Holding & $\begin{array}{l}\text { Textile \& } \\
\text { garment; } \\
\text { white goods }\end{array}$ & Vestel; Taç & 241702007 & $\begin{array}{l}\text { www.vest- } \\
\text { el.com.tr } \\
\text { www.tac.com.tr }\end{array}$ \\
\hline Elginkan Holding & Durable goods & E.C.A.; Serel & $\mathrm{n} / \mathrm{a}$ & $\begin{array}{l}\text { www.valfsel.com } \\
\text { www.ser- } \\
\text { el.com.tr }\end{array}$ \\
\hline Koton Tekstil & $\begin{array}{l}\text { Textile \& } \\
\text { garment }\end{array}$ & Koton & $\mathrm{n} / \mathrm{a}$ & $\begin{array}{l}\text { www.ko- } \\
\text { ton.com.tr }\end{array}$ \\
\hline Novaplast Plastik & $\begin{array}{l}\text { Textile \& } \\
\text { garment }\end{array}$ & Vesbo & $\mathrm{n} / \mathrm{a}$ & www.vesbo.com \\
\hline Sabanci Holding & $\begin{array}{l}\text { Textile \& } \\
\text { garment; } \\
\text { automotive }\end{array}$ & Bossa; Temsa & $\begin{array}{l}159407211 \\
338046803\end{array}$ & $\begin{array}{l}\text { www.bos- } \\
\text { sa.com.tr } \\
\text { www.tem- } \\
\text { sa.com.tr }\end{array}$ \\
\hline Uki Konfeksiyon & $\begin{array}{l}\text { Textile \& } \\
\text { garment }\end{array}$ & Uki & $\mathrm{n} / \mathrm{a}$ & www.uki.com.tr \\
\hline Zen Pirlanta & $\begin{array}{l}\text { Textile \& } \\
\text { garment }\end{array}$ & Zen & $\mathrm{n} / \mathrm{a}$ & $\begin{array}{l}\text { www.zenpirlan- } \\
\text { ta.com }\end{array}$ \\
\hline Sun Holding & $\begin{array}{l}\text { Textile \& } \\
\text { garment }\end{array}$ & Jimmey Key & $\mathrm{n} / \mathrm{a}$ & $\begin{array}{l}\text { www.jkey- } \\
\text { land.com }\end{array}$ \\
\hline Yasar Holding & $\begin{array}{l}\text { Textile \& } \\
\text { garment }\end{array}$ & Pinar & 25000000 & $\begin{array}{l}\text { www.pi- } \\
\text { nar.com.tr }\end{array}$ \\
\hline Taris Zeytin & $\begin{array}{l}\text { Non-durable } \\
\text { goods }\end{array}$ & Ta-ze & $\mathrm{n} / \mathrm{a}$ & $\begin{array}{l}\text { www.tariszey- } \\
\text { tin.com.tr }\end{array}$ \\
\hline
\end{tabular}

\section{Discussion}

Much has been said and done so far. The outcome should appear as 'ten world brands in ten years' - but, there is no benchmark or analogous project in the world with 
which to compare this one. Nevertheless, one may argue that a collective effort on such scale must bear some fruit. Governments in other countries like Mexico, ${ }^{2}$ Brazil, Tunisia and India ${ }^{3}$ have also been particularly active in supporting - at least initially their textile and apparel industry in this phase of market transformation, i.e. in providing marketing and industrial support. Forms of industrial support can be seen as, for example, the 'de-taxation of research and development expenditures (EU)', the 'accelerated depreciation of certain types of equipment (service oriented)', sectoral benchmarking and improvement support services as in Mexico, India, Egypt, Cambodia, Dominican Republic... and the EU) and exposure to best practices including seminars, executive workshops, etc. ${ }^{4}$

Some of the certified companies were, in the beginning, worried that the Turquality label would shade their brand(s), which had already gained brand recognition in the world. However, the authors would like to underline the need for a detailed assessment of the project after four years of experience: qualitative research needs to be conducted in order to see the strengths and weaknesses of the Turquality concept in the period 'so far'.

\section{References}

Al-Sulaiti, K and M. J Baker (1998) 'Country-of-origin effects: a literature review' Marketing Intelligence and Planning 16(3).

Baker, M. J and C. A Currie (1993) Country of Origin: the fifth element of the marketing mix? Marketing Education Group Conference.

Bannister, J. P and J. A Saunders (1978) 'UK consumers' attitudes towards imports: the measurement of national stereotype image' European Journal of Marketing 12(8).

Bilkey, W. J and E. Nes (1982) 'Country of origin effects on product evaluation' Journal of International Business Studies 8(1), Spring/Summer.

Chasin, J. and E. Jaffe (1979) 'Industrial buyer attitudes toward goods made in eastern Europe' Columbia Journal of World Business 14, Summer.

Clarke, Irvine, Margaret Owens and John Ford (2000) 'Integrating country of origin into global marketing strategy' International Marketing Review 17(2).

Chao, P (1993) 'Partitioning country of origin effects on product evaluations of a hybrid product' Journal of International Business Studies 24(2).

Cordell, V. V (1992) 'Effects of consumer preferences for foreign sourced products' Journal of International Business Studies 23(2).

Han, C. M (1989) 'Country image: halo or summary construct?' Journal of Marketing Research 26, May.

Han, C. M and V. Terpstra (1988) 'Country of origin effects for uni-national and binational products' Journal of International Business Studies 19, Summer.

2 Canaintex (www.canaintex.org.mx).

3 Ministry of Industry.

4 Presentation notes of Gian Mario Borney of Werner International. 
Heslop, L. A and N. Papadopoulos (eds.) (1993) Product-country images: Impact and role in International Marketing Haworth Press: New York.

Hong, S and R. S Wyer (1989) 'Effects of country of origin and product attribute on product evaluation: an information processing perspective Journal of Consumer Research 16.

Hong, S and R. S Wyer (1990) 'Determinants of product evaluation: effects of the time interval between knowledge of a product's country of origin and information about its specific attributes' Journal of Consumer Research 17.

Johanson, J. K, S. P Douglas and I. Nonaka (1985) 'Assessing the impact of country of origin on product evaluations: a new methodological perspective' Journal of Marketing Research 22.

Khachaturian, J. L and M. A Morganosky (1990) 'Quality perceptions by country of origin' International Journal of Retail \& Distribution Management 18(5).

Lee, D and C. Schaninger (1996) 'Country of production/assembly as a new country image construct: a conceptual application to global transplant decision' Advance in International Marketing 7.

Moore, T. P (1996) 'Problems with country of origin marking' Logistics Management 35(11), November.

Nagashima, A (1970) 'A comparison of Japanese and US attitudes toward foreign products' Journal of Marketing 34.

Nes, E and W. J Bilkey (1993) in L. A Heslop and N. Papadopoulos (eds.) ProductCountry Images: Impact and Role in International Marketing Haworth Press: New York.

Ozsomer, A and S. Cavsugil (1991) 'Country of origin effects on product evaluations: a sequel to Bilkey and Nes review' in Gilly et al. (eds.) AMA Educators Proceedings 2, Chicago.

Papadopoulos, N (1993) 'What product country images are and are not' in N. Papadopoulos and L. Heslop (eds.) Product Country Images International Business Press: New York.

Papadopoulos, N, L. Heslop, F. Graby, F and G. Avlonitis (1987) Does country of origin matter? Some findings from a cross-cultural study of consumer views about foreign products Report No. 87-104, Marketing Science Institute: Cambridge, MA.

Samiee, S (1994) 'Customer evaluation of products in a global market' Journal of International Business Studies 25(3).

Schooler, R. D (1965) 'Product bias in the central American common market' Journal of Marketing Research November.

Thorelli, H. B, J. Lim and J. Ye (1989) 'Relative importance of country of origin, warranty and retail store image on product evaluation' International Marketing Review 6(1).

Tse, A, C. Kwan, C. Yee, K. Wah and L. Ming (1996) 'The impact of country of origin on the behaviour of Hong Kong consumers' Journal of International Marketing \& Marketing Research 21(1). 
Wang, C and C. Lamb (1983) 'The impact of selected environmental forces upon consumers' willingness to buy foreign products' Journal of the Academy of Marketing Science 11(2).

White, P. D and E. W Cundiff (1978) 'Assessing the quality of industrial products' Journal of Marketing 42, January.

OECD policy brief A New World Map in Textiles and Clothing October 2004.

Milliyet newspaper (www.milliyet.com.tr), 14 December 2006.

Hurriyet newspaper (www.hurriyet.com.tr) 14 December 2006.

www.itkib.org.tr

www.turquality.com.tr

www.tim.org.tr

www.dtm.gov.tr

www.igeme.gov.tr

www.basbakanlik.gov.tr

www.turkishdailynews.com.tr

www.tuik.gov.tr/PreIstatistikTablo.do?istab_id=513

www.canaintex.org.mx

Presentation notes of Mr Gian Mario Borney, Vice-President of Werner International.

\section{Endnotes}

Union of Istanbul Textile and Ready-to-wear Exporters (ITKİB)

Turkish Statistical Institute (TÜIK-TURKSTAT) 